Please do not remove this page

RMIT

UNIVERSITY

\title{
Assessment framework for the impacts of climate change and urbanization on urban drainage systems
}

Tran, Huu; Molavi, S.; Muttil, N.

https://researchrepository.rmit.edu.au/esploro/outputs/9921858130501341/filesAndLinks?institution=61RMIT_INST\&index=null

Tran, H., Molavi, S., \& Muttil, N. (2011). Assessment framework for the impacts of climate change and urbanization on urban drainage systems. Pipelines 2011: A Sound Conduit for Sharing Solutions, 1403-1412. https://doi.org/10.1061/41187(420)129

Document Version: Accepted Manuscript

Published Version: https://doi.org/10.1061/41187(420)129

Repository homepage: https://researchrepository.rmit.edu.au

(C) ASCE 2011

Downloaded On 2023/04/26 22:12:21 +1000

Please do not remove this page 
Thank you for downloading this document from the RMIT Research Repository.

The RMIT Research Repository is an open access database showcasing the research outputs of RMIT University researchers.

RMIT Research Repository: http://researchbank.rmit.edu.aul

\section{Citation: \\ Tran, H, Molavi, S and Muttil, N 2011, 'Assessment framework for the impacts of climate change and urbanization on urban drainage systems', in "David" Hyung Seok Jeong, Ph.D.; Dan Pecha, P.E. (ed.) Pipelines 2011: A Sound Conduit for Sharing Solutions, Seattle, United States, 23 -27 July 2011, pp. 1403-1412.}

See this record in the RMIT Research Repository at:

https://researchbank.rmit.edu.au/view/rmit:18619

Version: Accepted Manuscript

Copyright Statement:

(C) ASCE 2011

Link to Published Version:

http://dx.doi.org/10.1061/41187(420)129 


\title{
Assessment Framework for the Impacts of Climate Change and Urbanization on Urban Drainage Systems
}

\author{
H. D. Tran ${ }^{1,2}$, S. Molavi ${ }^{1}$ and N. Muttil ${ }^{1}$ \\ ${ }^{1}$ School of Engineering and Science, Victoria University, PO Box 14428, Melbourne, \\ Vic. 8001, Australia; email: dung.tran@vu.edu.au ; shahram.molavi@live.vu.edu.au ; \\ nitin.mutill@vu.edu.au \\ ${ }^{2}$ Institute of Sustainability and Innovation, Victoria University, Australia
}

\begin{abstract}
It has been widely recognized that global climate change will have negative impacts not only on the natural environment but also on the human-built environment. This paper describes the framework developed to assess the potential impacts of climate change and urbanization on drainage systems of Australian urban cities. One of real concerns is how the flooding risk will change over the next 5-25 years under such possible impacts. In this study, the assessment method is explored with regards to two major effects of climate change (i.e. changed pattern of storm event and rising sea level), two effects of urbanization (i.e. increasing impervious area and storm water harvesting) and two effects of hydraulic deterioration (i.e. reduced cross-sectional area and increased internal surface roughness of conduits). The framework is demonstrated on a simulation study at street. The outcomes of this study will provide preliminary understanding on how drainage systems respond to changing climate inputs and also guided steps to implement the framework on real-world problems.
\end{abstract}

\section{INTRODUCTION}

Urban drainage systems are an important part of the Australian water infrastructure that removes only stormwater runoff from urban cities. They are managed by local city governments and their catchment size ranges from 200 ha $-5,000$ ha (Urban Cities of Victoria State, Australia).

Sustaining an acceptable risk of urban flooding is one of the key objectives in operational planning and management of urban drainage systems. This is because flooding causes multi-dimensional damages which include social discomfort, economical cost and even political loss. Therefore, there is a need to assess the flooding impact of climate change on urban drainage systems so that appropriate risk management strategies can be applied.

Rising sea level and increasing rainfall extremes are increasingly recognized as one of many impacts due to climate changes (Larsen et al., 2008). From urban drainage engineering point of view, these two impacts potentially increase the risk of urban flooding. This is because urban drainage systems are commonly designed based on peak flow (i.e. rainfall extremes) and are discharged directly into river or ocean which is dependent on sea level (Mailhot and Duchesne, 2010). 
This paper presents a framework for impact assessment of climate change on urban drainage systems in terms of urban flooding. The framework can be adapted to different urban drainage systems managed by local City Governments. To make the framework close to reality, other factors affecting urban flooding are also considered. They are urbanization, stormwater harvesting, stormwater detention and hydraulic deterioration of stormwater conduits. The framework applicability is illustrated using a simple simulation study at street level of an urban site with the aid of SWMM software package.

\section{BACKGROUND}

\section{Climate Change and Urban Flooding}

Risk of urban flooding was traditionally assessed using simulation of time series analysis of rainfall data (Olsson et al., 2009). This approach means that rainfall patterns in the past will continue in the future given that some random noise and average trend may exist. However, the human-induced climate change poses a new challenge to this approach since rainfall pattern may shift to a whole new level.

It comes to the alternative approach of physically-based models which was developed as global climate models (GCMs) and can physically explain climate change in the future. This approach emphasized that greenhouse gas $\left(\mathrm{CO}_{2}\right)$ emission is the major cause of global warming and climate change. Based on 8 scenarios of global produce of $\mathrm{CO}_{2}$ emission over the next 100 years and sophisticated GCMs, the Intergovernmental panel on climate change (Intergovernmental Panel on Climate Change (IPCC), 2007) projected that global warming and climate change will include increase in temperature, increase in extreme rainfall events and increase in sea level.

However, GCMs based rainfall projection is spatially much coarser (i.e. 200x200 km) than considered regional climate $(10 \mathrm{x} 10 \mathrm{~km})$, especially for urban catchments which may require even finer level of $5 \times 5 \mathrm{~km}$ (Mailhot et al., 2007). Furthermore, the temporal resolution of GCM based rainfall projection is at best as daily scale since sub-daily scale requires much more inputs to run GCMs. Apparently, proper assessment of urban flooding requires hourly or even shorter time scale of rainfall projection. Several urban flooding studies have addressed the spatial and temporal issues of GCM based rainfall projection as reported by Olsson et al. (2009).

The first approach is known as statistical downscaling as described in Nguyen et al. (2007, 2010). They used the statistical downscaling model and the scaling general extreme value distribution to spatially and temporally downscale GCM based rainfall projection to local site ranging $0.4-10$ hectares and $5 \mathrm{~min}$ to 1-day duration.

The second approach utilized regional climate models as shown in Mailhot at el. (2007) that used the Canadian regional climate model to produce sub-daily IDF curves at $45 \times 45$ $\mathrm{km}$ grid box for the Quebec region between the years 2040-2070. They found that return periods over the grid box area can be approximately halved for events with return periods ranging between 20 and 50 years in present climate. They also applied the delta change method to convert IDF curves from area values to point values at the rain gauge station. 


\section{Other Factors Affecting Urban Flooding}

Impervious area: this is one of distinctive attributes of urban catchments that facilitate flash flooding. A study in UK has practically demonstrated how progressive urbanization (i.e. increase of impervious areas) can lead to surface and property flooding (Swan, 2010). The study then outlines how these problems might be reversed using both 'quick fix' and 'long-term' remediation strategies and explores the respective merits of both approaches. While current impervious area can be estimated using aerial photographs and remote sensing techniques, the challenge is to predict the increase rate of impervious area in the future so that flooding risk assessment can be properly done.

Downstream water level: Australian urban cities often discharge stormwater runoff directly to adjacent catchments and eventually to the ocean or rivers. When the downstream water level is increased, the upstream level will be affected and thus cause flooding. Global climate change also causes sea level rise (Michael, 2007). However, estimates of future sea level rise are subject to considerable uncertainty as a result of assumptions made concerning future emission scenarios, the impact of this radiative forcing on the atmosphere, the rate of heat penetration into the oceans and uncertainty over the response of the ice caps and ice-sheets to climate change (Purvis et al., 2008). The challenge is to assess how sea level will rise at a particular coastline in the future given such existing uncertainty and how this will impact on flooding risk of connected urban catchments?

Condition of drainage system (i.e. collecting pits and conveying pipes): Hydraulic deterioration of drainage components including pits and pipes is the accumulation process of debris and encrustation, which reduces cross-sectional area and increases surface roughness (Tran et al., 2006). The challenge is how to predict hydraulic deterioration in the future. The baseline is the comparison between no cleaning and annual cleaning.

Stormwater harvesting: There is an increasing interest to harvest stormwater at the household level (through water tanks) and at the commercial level (through constructed wetlands or other forms as part of water sensitive urban design) in urban cities with water shortage. The stormwater harvesting will have a positive impact on reducing stormwater runoff and subsequently flooding risk (Wheater and Evans, 2009). The challenge is how to estimate the increase rate of stormwater harvesting and take this factor into flooding risk assessment.

\section{FRAMEWORK OF IMPACT ASSESSMENT}

The assessment framework of climate change impact on urban flooding consists of 5 phases. They are designed to address practical issues in urban drainage modeling such as data collection and uncertainty analysis. The descriptions of these five phases are shown as follows.

\section{Phase 1: Data Collection Program.}

Recommended data collection program is shown in Table 1. 
Table 1: Data to be collected and collection method

\begin{tabular}{lll}
\hline \multicolumn{1}{c}{ Data group } & \multicolumn{1}{c}{ Detailed } & \multicolumn{1}{c}{ Collection methods } \\
\hline Catchment surface & $\begin{array}{l}\text { Impervious area } \\
\text { Land strata }\end{array}$ & City Council's GIS database \\
\hline Drainage system & Coordinates & City Council's GIS database \\
& Pipe diameter & \\
& Pipe age & \\
& Pipe depth & \\
& CCTV data & \\
\hline Runoff (or discharge) & Catchment runoff & Flowmeters to be installed \\
& Sub-catchment runoff & \\
\hline Rainfall & Catchment level & Rain gauges to be installed \\
& Sub-catchment level & \\
\hline Climate & Global rainfall projection & GCM or RCM outputs \\
& Sea level rise & \\
& Temperature rise & \\
\hline
\end{tabular}

\section{Phase 2: Urban Drainage Model}

The simulation tool is based on SWMM version 5.0 which is developed by US EPA (2010) and is freely downloadable. SWMM is a dynamic rainfall-runoff simulation model used for single event or long-term (continuous) simulation of runoff quantity and quality from primarily urban areas. The runoff component of SWMM operates on a collection of sub catchment areas that receive precipitation and generate runoff. The routing portion of SWMM transports this runoff through a system of pipes, channels, storage/treatment devices, pumps, and regulators comprising of multiple time steps to assess the response of components.

Table 2 shows components of urban catchment that are modeled in the SWMM. An illustrated process of modeling an urban street into SWMM is shown in Figures 1-3. Figure 1 shows an aerial photograph of an urban street with mixing of impervious and pervious areas. Figure 2 shows the layer of land size and boundary. Figure 3 models each household as a sub-catchment. Furthermore, street surface is also divided into a number of sub-catchments whose runoffs are designated to corresponding collection pits. The modeling process can be done manually or automatically through an excel file format. Such a modeling approach allows the inclusion of water tank and land use changes. 
Table 2: Components of the urban drainage models

\begin{tabular}{|c|c|}
\hline Model components & Description \\
\hline Urban Catchment & $\begin{array}{l}\text { The whole catchment managed by the Local City } \\
\text { Government. }\end{array}$ \\
\hline \multirow[t]{4}{*}{ Sub-catchments } & $\begin{array}{l}\text {-Households, parks, streets and buildings are modeled } \\
\text { as a sub-catchment. This allows changing impervious } \\
\text { area and runoff coefficient at individual levels. }\end{array}$ \\
\hline & $\begin{array}{l}\text {-Residential areas are considered impervious while } \\
\text { front and backyards are considered pervious area. } \\
\text { Assumption is } 60 / 40 \text { impervious/pervious }\end{array}$ \\
\hline & $\begin{array}{l}\text {-Streets are considered as } 100 \% \text { impervious sub- } \\
\text { catchments. }\end{array}$ \\
\hline & $\begin{array}{l}\text {-Stormwater runoff of household and street surface is } \\
\text { supposed to connect to the street junction. }\end{array}$ \\
\hline Junction & $\begin{array}{l}\text { Street junctions are considered connection point for } \\
\text { sub-catchments and conduits. }\end{array}$ \\
\hline Detention & Detention is modeled as storage unit. \\
\hline \multirow[t]{2}{*}{ Conduits } & -Circular and concrete conduits \\
\hline & $\begin{array}{l}\text {-Hydraulic deterioration is modeled through diameter } \\
\text { change and roughness coefficients. }\end{array}$ \\
\hline \multirow[t]{2}{*}{ Outfall } & -Stormwater runoff is discharged through the outfall. \\
\hline & $\begin{array}{l}\text {-Rising sea level can be modeled through the outfall } \\
\text { water level. }\end{array}$ \\
\hline Rain gages & $\begin{array}{l}\text { Timely distribution of rainfall can be entered using } \\
\text { internal dialog or external file. }\end{array}$ \\
\hline
\end{tabular}

\section{Phase 3: Model Calibration}

This model calibration phase is to estimate model parameters so that the model-produced runoff is consistent with observed runoff. The crucial data is measured runoff. Where runoff data is available for calibrating model parameters, the models work very well. But 40 years of effort by many researchers in many countries has not produced much success in modeling runoff on ungauged catchments (Boughton, 2009). A preliminary discussion indicated that many local City Governments do not have flowmeters in place and thus installation of flowmeters is recommended. 
Two generally applicable classes of approach are potentially available to handle the model calibration for ungauged catchments. They are both based on making use of information from a large set of gauged sites for which substantial flow records are available. Approaches in the first class work directly with the statistical distributions of extreme events for the collection of gauged sites: often the analysis relates to the distribution of annual maximum peak flows. Relations are sought between these statistical distributions and the catchment descriptors and are then used to derive estimates for the statistical distribution of extreme events for a target catchment based on its known catchment descriptors (Jones and Kay, 2007). However, "All of the studies examined here reported relatively low correlations between model parameters and catchment attributes." (Boughton, 2009).

Transfer of hydrological information from one or more gauged catchments to the ungauged catchment by extrapolation from the gauged data, observation by remote sensing, hydrological model simulation and integrated meteorological and hydrological modeling are recognized as the second potential predictive approach (Goswami et al., 2007, Li et al., 2009).

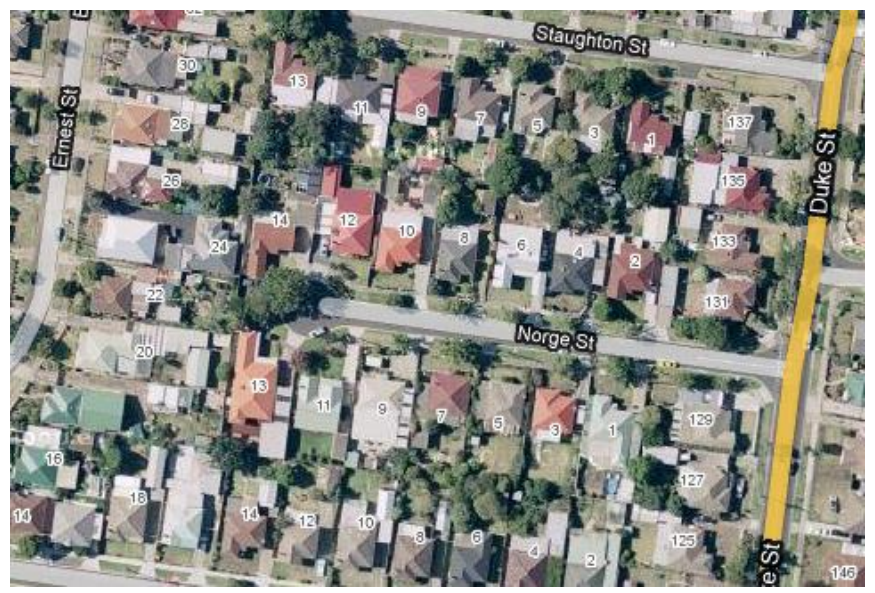

Figure 1. Satellite view of urban streets

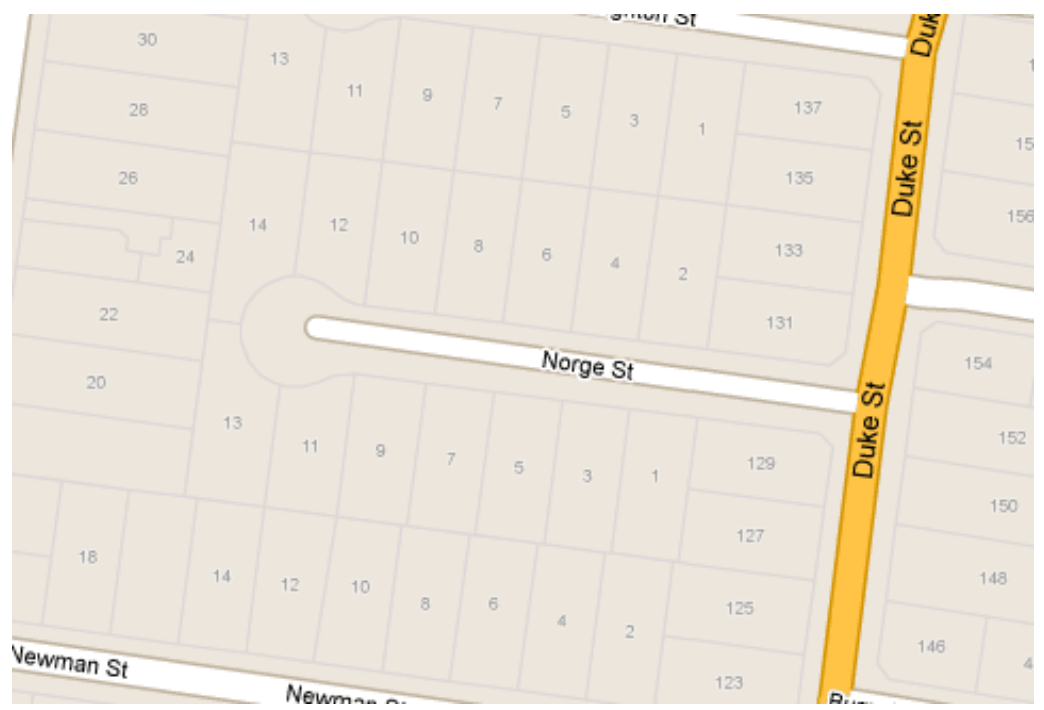


Figure 2. Land use of the 'Norge' street

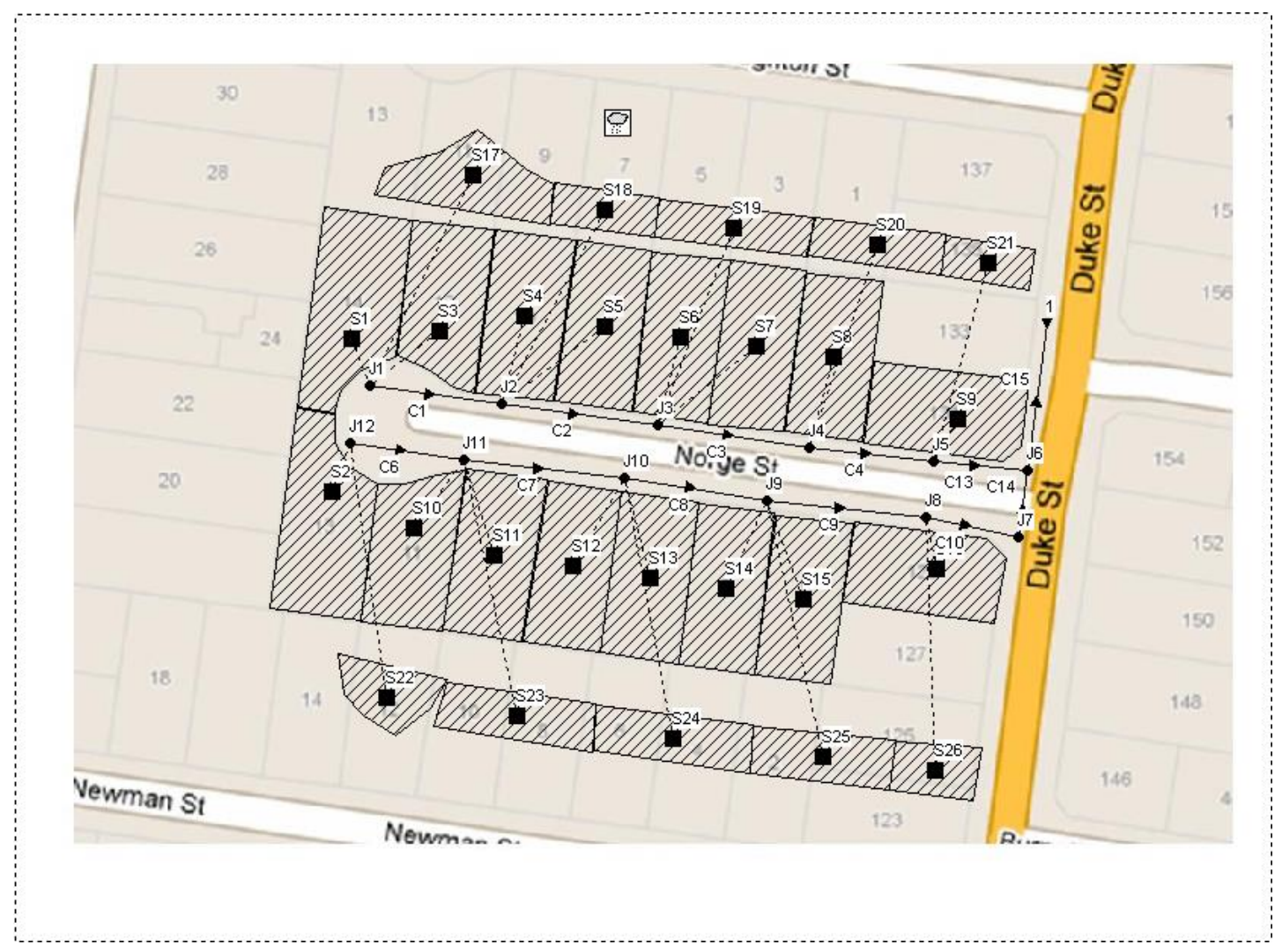

Figure 3. Urban drainage model at a street level

\section{Phase 4: Development of Prediction Models}

The prediction models for the following factors can be developed to reflect flooding risk in the future between the years 2030-2100:

- Rainfall projection through statistical downscaling (Nguyen et al., 2007) or dynamics downscaling (i.e. regional climate modeling) of GCM outputs (Olsson et al., 2009).

- Rising sea level through GCM outputs (Karim and Mimura, 2008).

- Increasing rate of impervious area (Schueler et al., 2009) can be modeled using multiple linear regression (Chabaeva et al., 2009) or a power law model.

- Pipe hydraulic deterioration. Tran et al. $(2006,2008)$ have developed the Markov model and neural network model to predict the hydraulic condition of pipes.

- Rate of stormwater harvesting can be modeled using exponential or straight line model.

\section{Phase 5: Performing Simulation}


The simulation can be performed based on different scenarios. Each scenario can be generated by changing the following factors.

1. Rainfall extreme (30\% increase)

2. Impervious area (increase from $60 \%$ to $80 \%$ )

3. Downstream water level (unchanged)

4. Condition of drainage system (i.e. pits and pipes)

(50\% reduction of cross-sectional area and $100 \%$ increase in roughness)

5. Stormwater harvesting (unchanged)

6. Stormwater detention (unchanged)

Some factors will be based on prediction models developed in Phase 4. Values in bracket indicate the hypothetical change between current year of 2010 and future of 2040 for the illustration of simulation.

Table 4 shows the simulation results between two hypothetical scenarios in which one scenario is the current condition at 2010 and another scenario (in bold) is at 2040. It can be seen from the table that such hypothetical increases in rainfall extreme and impervious area can cause overflow in conduits 1-4 (where Max / Full depth equal to 1) and consequently flooding in corresponding junctions. Based on that, mitigation measures such as regular pipe cleaning and control of impervious area can be adopted.

Table 4. Simulation results

\begin{tabular}{llrrrrrr}
\hline Link & Type & $\begin{array}{r}\text { Max } \\
\text { flow }\end{array}$ & \multicolumn{2}{c}{$\begin{array}{r}\text { Time of max. } \\
\text { occurrence }\end{array}$} & $\begin{array}{r}\text { Max } \\
\text { Velocity }\end{array}$ & $\begin{array}{r}\text { Max/Full } \\
\text { Flow }\end{array}$ & $\begin{array}{r}\text { Max / Full } \\
\text { Depth }\end{array}$ \\
\hline C1 & CONDUIT & 0.021 & 0 & $0: 46$ & 0.73 & 0.17 & 0.28 \\
\hline & & $\mathbf{0 . 0 1}$ & $\mathbf{0}$ & $\mathbf{1 : 1 8}$ & $\mathbf{0 . 4 4}$ & $\mathbf{1 . 0 8}$ & $\mathbf{1}$ \\
\hline C2 & CONDUIT & 0.041 & 0 & $0: 46$ & 0.88 & 0.34 & 0.4 \\
\hline & & $\mathbf{0 . 0 1}$ & $\mathbf{0}$ & $\mathbf{1 : 2 5}$ & $\mathbf{0 . 3 9}$ & $\mathbf{1 . 0 8}$ & $\mathbf{1}$ \\
\hline C3 & CONDUIT & 0.061 & 0 & $0: 46$ & 0.97 & 0.51 & 0.5 \\
\hline & & $\mathbf{0 . 0 1}$ & $\mathbf{0}$ & $\mathbf{1 : 3 4}$ & $\mathbf{0 . 4}$ & $\mathbf{1 . 0 6}$ & $\mathbf{1}$ \\
\hline C4 & CONDUIT & 0.074 & 0 & $0: 46$ & 1.02 & 0.61 & 0.56 \\
\hline & & $\mathbf{0 . 0 1}$ & $\mathbf{0}$ & $\mathbf{1 : 3 9}$ & $\mathbf{0 . 4}$ & $\mathbf{1 . 0 6}$ & $\mathbf{1}$ \\
\hline C15 & CONDUIT & 0.173 & 0 & $0: 47$ & 2.02 & 0.11 & 0.23 \\
\hline & & $\mathbf{0 . 0 2 4}$ & $\mathbf{0}$ & $\mathbf{1 : 2 1}$ & $\mathbf{0 . 7 5}$ & $\mathbf{0 . 1 9}$ & $\mathbf{0 . 3}$ \\
\hline
\end{tabular}

\section{Phase 6: Uncertainty Analysis}

Probabilistic prediction of mathematical models is more realistic than point (or deterministic) prediction because it addresses the uncertainty of the underlying and modeling processes. The interval values coming from the probabilistic prediction are 
considered as the quantification of the uncertainty and are useful for risk assessment (Borsuk and Tomassini, 2005).

Sources of uncertainty in mathematical models come from input uncertainty (due to measurement error and imprecise information) (Kleidorfer et al., 2009), quantity and quality of calibration data (i.e. sufficient sample size and representative sample) (De Michele and Salvadori, 2005), calibration of model parameters (i.e. local optimum) (Kuczera et al., 2006) and choice of model types (Cloke and Pappenberger, 2009).

The use of urban drainage models requires careful calibration, where model parameters are selected in order to minimize the difference between measured and simulated results (Kleidorfer et al., 2009). It has been recognized that often more than one set of calibration parameters can achieve similar model accuracy. A probability distribution of model parameters should therefore be constructed to examine the model's sensitivity to its parameters. It also becomes important to analyze the model parameter sensitivity while taking into account uncertainties in input and calibration data.

\section{SUMMARY}

This paper presents a proposed framework for impact assessment of climate change on urban flooding using a conceptual rainfall runoff model. The major objective is to investigate how such a modeling tool can be used to provide useful information for operational, tactical and strategic asset management strategies. The assessment framework consists of 5 phases which are designed to address practical issues in urban drainage modeling, such as data collection and uncertainty analysis. The preliminary simulation of an urban street shows interesting results of overflow under one scenario of climate change and other factors such as increase of impervious area. Based on that, mitigation measures such as regular pipe cleaning and control of impervious area can be adopted.

\section{ACKNOWLEDGMENT}

Support and free download of SWMM 5 from US EPA is acknowledged.

\section{REFERENCES}

Borsuk, M. E. \& Tomassini, L. (2005) "Uncertainty, Imprecision, and the Precautionary Principle in Climate Change Assessment." Water Science and Technology, 52(6), 213-225.

Boughton, W. (2009) "New Approach to Calibration of the AWBM for Use on Ungauged Catchments." Journal of Hydrologic Engineering, 14(6), 562-568.

Chabaeva, A., Civco, D. L. \& Hurd, J. D. (2009) "Assessment of Impervious Surface Estimation Techniques.” Journal of Hydrologic Engineering, 14(4), 377-387.

Cloke, H. L. \& Pappenberger, F. (2009) "Ensemble flood forecasting: A review." Journal of Hydrology, 375(3-4), 613-626.

De Michele, C. \& Salvadori, G. (2005) "Some hydrological applications of small sample estimators of Generalized Pareto and Extreme Value distributions." Journal of Hydrology, 301(1-4), 37-53.

Goswami, M., O'connor, K. M. \& Bhattarai, K. P. (2007) "Development of regionalisation procedures using a multi-model approach for flow simulation in an ungauged catchment." Journal of Hydrology, 333(2-4), 517-531. 
Intergovernmental Panel on Climate Change (IPCC) (2007) "The Physical Science Basis. Contribution of Working Group I to the Fourth Assessment Report of the Intergovernmental Panel on Climate Change." Cambridge University Press, Cambridge.

Jones, D. A. \& Kay, A. L. (2007) "Uncertainty analysis for estimating flood frequencies for ungauged catchments using rainfall-runoff models." Advances in Water Resources, 30(5), 1190-1204.

Karim, M. F. \& Mimura, N. (2008) "Impacts of climate change and sea-level rise on cyclonic storm surge floods in Bangladesh." Global Environmental Change, 18(3), 490-500.

Kleidorfer, M., Deletic, A., Fletcher, T. D. \& Rauch, W. (2009) "Impact of input data uncertainties on urban stormwater model parameters." Water Science and Technology, 60(6), $1545-1554$.

Kuczera, G., Kavetski, D., Franks, S. \& Thyer, M. (2006) "Towards a Bayesian total error analysis of conceptual rainfall-runoff models: Characterising model error using stormdependent parameters." Journal of Hydrology, 331(1-2), 161-177.

Larsen, P. H., Goldsmith, S., Smith, O., Wilson, M. L., Strzepek, K., Chinowsky, P. \& Saylor, B. (2008) "Estimating future costs for Alaska public infrastructure at risk from climate change." Global Environmental Change, 18(3), 442-457.

Li, H., Zhang, Y., Chiew, F. H. S. \& Xu, S. (2009) "Predicting runoff in ungauged catchments by using Xinanjiang model with MODIS leaf area index." Journal of Hydrology, 370(1-4), 155162.

Mailhot, A. \& Duchesne, S. (2010) "Design Criteria of Urban Drainage Infrastructure under Climate Change." Journal of Water Resources Planning and Management, 136(2), 201-208.

Mailhot, A., Duchesne, S., Caya, D. \& Talbot, G. (2007) "Assessement of Future Change in Intensity-Duration-Frequency (IDF) Curves for Southern Quebec Using the Canadian Regional Climate Model (CRCM).” Journal of Hydrology, 347(1-2), 197-210.

Michael, J. A. (2007) "Episodic flooding and the cost of sea-level rise." Ecological Economics, 63(1), 149-159.

Nguyen, V.-T.-V., Desramaut, N. \& Nguyen, T.-D. (2010) "Optimal Rainfall Temporal Patterns for Urban Drainage Design in the Context of Climate Change." Water Science and Technology, 62(5), 1170-1176.

Nguyen, V.-T.-V., Nguyen, T.-D. \& Cung, A. (2007) "A Statistical Approach to Downscaling of Sub-Daily Extreme Rainfall Process for Climate-related Impacts Studies in Urban Areas." Water Science and Technology: Water Supply, 7(2), 183-192.

Olsson, J., Berggren, K., Olofsson, M. \& Viklander, M. (2009) "Applying climate model precipitation scenarios for urban hydrological assessment: A case study in Kalmar City, Sweden." Atmospheric Research, 92, 365-375.

Purvis, M. J., Bates, P. D. \& Hayes, C. M. (2008) "A probabilistic methodology to estimate future coastal flood risk due to sea level rise." Coastal Engineering, 55(12), 1062-1073.

Schueler, T. R., Fraley-Mcneal, L. \& Cappiella, K. (2009) "Is Impervious Cover Still Important? Review of Recent Research." Journal of Hydrologic Engineering, 14(4), 309-315.

Swan, A. (2010) "How increased urbanisation has induced flooding problems in the UK: A lesson for African cities?" Physics and Chemistry of the Earth, Parts A/B/C, 35(13-14), 643-647.

Tran, D. H., Ng, A. W. M., Mcmanus, K. J. \& Burn, S. (2008) "Prediction Models for Serviceability Deterioration of Stormwater Pipes." Structure and Infrastructure Engineering, 4(4), 287-295.

Tran, D. H., Ng, A. W. M. \& Perera, B. J. C. (2006) "A Hydraulic Performance Modelling Framework for Urban Stormwater Pipe Infrastructure Systems.", 30th Hydrology and Water Resources Symposium, Launcestor, Tasmania.

US EPA (2010) SWMM 5, User's Manual, US.EPA, Washington D.C.

Wheater, H. \& Evans, E. (2009) "Land use, water management and future flood risk." Land Use Policy, 26(Supplement 1), S251-S264. 